CZASOPISMO INŻYNIERII LA¿OWEJ, ŚRODOWISKA I ARCHITEKTURY JOURNAL OF CIVIL ENGINEERING, ENVIRONMENT AND ARCHITECTURE

JCEEA, t. XXXIV, z. 64 (3/II/17), lipiec-wrzesień 2017, s. 467-485, DOI:10.7862/rb.2017.187

Zbigniew K. ZUZIAK ${ }^{1}$

\title{
KONSTRUKCJE URBANISTYCZNE MIAST PRZYSZŁOŚCI. UWAGI DO DYSKUSJI NAD WIZJĄ ROZWOJU RZESZOWA
}

\begin{abstract}
Artykuł dotyczy roli modelowania w planowaniu przestrzennym miast, które rozwijają swój potencjał metropolitalny i aspirują do miana miasta przyszłości. Zakładając, że budowa miasta przyszłości wymaga zmian o charakterze modelowym zwłaszcza w relacjach: transport i użytkowanie terenu - zarysowano koncepcję modelu, który byłby narzędziem planistycznym odpowiadającym takiemu celowi. W tej części publikacji wykorzystano rezultaty projektu badawczego opracowanego, w latach 2016-17, przez zespół architektów, urbanistów i inżynierów transportu z Politechniki Krakowskiej. Projekt dotyczył modelowej interpretacji konstrukcyjnych, morfologicznych i funkcjonalnych atrybutów przestrzennej struktury Krakowa. W artykule akcent położono na konstrukcyjne aspekty tej interpretacji. Stąd kluczowa rola takich pojęć jak: zintegrowanie (connectivity), ,konstrukcja urbanistyczna”, sieć przestrzeni publicznych i „strategiczne wiązania” (strategic connectors). To ostatnie pojęcie oznacza miejskie korytarze wiążące główne klastry miejsc węzłowych a zarazem kierunki wzdłuż których należałoby skupiać strategiczne projekty miejskie celem uzyskania efektu synergii. Aczkolwiek model opracowano dla Krakowa, wskazano też na możliwości jego zastosowania w przypadku Rzeszowa. Zwrócono tu uwagę na potrzebę wzmocnienia „strategicznych wiązań” integrujących śródmiejskie węzły miejskości z innymi, kluczowymi elementami przestrzennej struktury metropolitalnej. Podkreślono strukturotwórczą rolę węzłów i korytarzy miejskości o różnych cechach morfologicznych i funkcjonalnych. Mowa tu również o konstrukcyjnych powiązaniach takich obszarów strategicznych jak: historyczne centrum, rejon głównego dworca kolejowego, rejon portu lotniczego, a także potencjalne obszary rewitalizacji terenów poprzemysłowych. W tym sensie kreowanie nowej wizji rozwoju Rzeszowa jako miasta przyszłości wiązałoby się z tworzeniem synergicznych relacji między konstrukcyjnymi, funkcjonalnymi i morfologicznymi warstwami modelu planistycznego. Zakłada się, że prezentowy model mógłby być podstawą badań porównawczych nad zmianami struktury przestrzennej takich miast jak: Kraków, Lublin, Rzeszów.
\end{abstract}

Słowa kluczowe: urbanistyka, planowanie przestrzenne, konstrukcja urbanistyczna, model struktury przestrzennej miasta, strategiczne wiązania, synergia urbanistyczna

${ }^{1}$ Zbigniew K. Zuziak, Politechnika Krakowska, ul. Mikołajska 4/2, 31-027 Kraków; tel.: 12421 3511;e-mail: zkzuziak@gmail.com 


\section{Wstęp: pytanie, cel, podejście}

Koncepcje miast idealnych i wizje miast przyszłości towarzyszą urbanistyce od jej zarania. Jednak zarówno lekcje historii jak i badania urbanistyki współczesnej wskazują, że w praktyce planowania urbanistycznego, odniesienia do ideałów i śmiałe spojrzenia w przyszłość, sprowadzają się najczęściej do strategicznych deklaracji, jakimi przesycone są założenia dokumentów planistycznych. Natomiast spójność realnych działań z wizjonerską retoryką - zwłaszcza gdy oceniamy ją z dłuższej perspektywy czasu - bywa zazwyczaj problematyczna. Urbanistyka współczesna daje bowiem dowody, że stosunkowo niewiele jest miast, w których długofalowa polityka rozwoju wyraża się konsekwentną realizacją modelu przyjętego w perspektywicznej wizji. W takim to kontekście pojawia się pytanie o rolę modelowania przestrzennej struktury miasta (PSM) w planowaniu urbanistycznym i urbanistyce operacyjnej. Wyartykułowanie stanowiska, które byłoby głosem w dyskusji nad tak postawionym pytaniem jest głównym celem tego artykułu. $\mathrm{W}$ prowadzonych tu rozważaniach skupiono się na planistycznych funkcjach modelowania miast rozwijających swój potencjał metropolitalny. Oznacza to sytuację, w której zajęcie możliwie wysokiej pozycji w rankingach „klubu miast przyszłości” jest jednym z priorytetów polityki rozwoju. W takim ujęciu planowanie miasta i kwestie modelowych interpretacji zmian w jego strukturze przestrzennej spotykają się z problemem projektowania nowych „konstrukcji urbanistycznych” (Zuziak Z. K., 2014, 2015, 2016, 2017). Budowa miast przyszłości oznacza bowiem zmiany o charakterze modelowym - zwłaszcza w relacjach: transport i użytkowanie terenu. Ale modelowanie PSM wiąże się również z problemem policentryczności i koniecznością wdrażania strategii zrównoważonej mobilności (Faron, 2010; Rudnicki, 2010; Szarata, 2010; Zuziak, 2010) [6 26 31].

\section{Modelowanie miasta przyszłości w urbanistyce współczesnej}

Formowaniu się struktur metropolitalnych nowej generacji towarzyszą procesy krystalizowania, w skali regionalnej i lokalnej, nowych układów policentrycznych. Na zjawisko to nakładają się również procesy transformacji struktur przestrzennych związanych z nauką, szkolnictwem wyższym, przemysłem wysokich technologii a także tworzenie się nowych form zagospodarowania przestrzennego, które odpowiadają dyfuzji innowacji w gospodarce (Domański, 2002; Boelens, 2009) [3 5]. W tych procesach strukturotwórczych istotną rolę odgrywa rewitalizacja obszarów kryzysowych (Zuziak, 2014, 2015) [47]. Przyjmując, że prezentowana tu koncepcja modelowania ma odzwierciedlać dynamikę tych zjawisk założono też, że konieczne jest otwarcie się planowania przestrzennego na innowacyjne procedury i techniki planistyczne a także na nowe koncepcje a skali architektoniczno-urbanistycznej. Odpowiada to zgłaszanym w literaturze urbanistycznej postulatom, że racjonalne i skuteczne oddziaływanie na zmiany dokonu- 
jące się w przestrzeni współczesnych miast oraz miejskich obszarów funkcjonalnych wymaga nowych narzędzi planistycznych (Boelens, 2009) [3]. Zarówno w teorii urbanistyki, jak i praktyce planowania miast, pojawiają się coraz to nowsze propozycje metodologiczne dotyczące rejestrowania i interpretowania zmian strukturalnych w przestrzeni zurbanizowanej (Domański, 2002 Haas, 2008). Analizy przykładów dobrej praktyki (Jessen i inni, 2008) [13] dowodzą, że zadaniom tym towarzyszyć muszą prace nad doskonaleniem technik zapisu planistycznego i metod wizualizacji zmian w przestrzennych strukturach miejskich. Mowa tu również o technikach które odpowiadałyby, zmieniającym się funkcjom, jakie współcześnie spełniać ma planowanie urbanistyczne, w tym: planistyczna notacja ustaleń polityki przestrzennej (Boelens, 2009; Thierstein, Förster, 2008) [3, 33].

Podobnie jak w innych dyscyplinach nauki, w urbanistyce i regionalistyce ${ }^{2}$ modele są konstruktami budowanymi na stosunkowo wysokim poziomie abstrakcji. Są systemami założeń, pojęć i symulacji kojarzących realne zmiany wyrażane w fizycznych, społeczno-ekonomicznych i kulturowych kategoriach przestrzeni miejskiej ze specyfiką procesów decyzyjnych właściwych danemu modelowi. Te intelektualne konstrukcje są uproszczonym opisem i interpretacją określonych aspektów rzeczywistości miejskiej ${ }^{3}$. Wyróżnia się tutaj modele opisowe (ang. descriptive $m$.), względnie wyjaśniające (explanatory m.), a modele będące narzędziami pomocnymi w udzielaniu odpowiedzi na pytania o prawdopodobne czy też pożądane kierunki rozwoju przestrzennej struktury miasta określa się jako probabilistyczne (probabilistic m.) lub normatywne (normative m.) ${ }^{4}$.

W stosunkowo bogatej literaturze przedmiotu spotyka się różne klasyfikacje modeli dotyczących rozwoju systemów transportowych i związków między tymi systemami a użytkowaniem terenu. W literaturze urbanistycznej znajdujemy też przykłady teorii rysujących szersze tło dla konceptualizacji tych związków i interpretacji tych mechanizmów strukturotwórczych, które można przełożyć na decyzje planowania urbanistycznego. Dla interesującego nas tematu jako szczególnie inspirujące wypada wskazać na takie nurty teorii modelowania jak: idea kodów generatywnych (Alexander, 2008), modele typu Space Syntax (Hillier B., 2008)[12], czy prace teoretyczne i badania kojarzace modele transportowe z modelami użytkowania terenu (Putman, S.H.: 2007; Zhong Chen, 2014) [24]. Do tego zbioru dodać też należy stosowane w regionalistyce modele kojarzące strukturotwórczą rolę transportu ze społecznymi, kulturowymi i ekonomicznymi (głównie rynkowymi) aspektami gospodarki przestrzennej i geografii osadnictwa (Domański, R., 2002) [5].

\footnotetext{
${ }^{2}$ R. Domański (2002) utożsamia regionalistykę z gospodarką przestrzenną.

${ }^{3}$ Dotyczy to również koncepcji modelowych traktujących miasto jako system złożony.

${ }^{4}$ Przegląd tych idei autor przedstawił w swojej publikacji pt.: Idea miasta i teorie planowania, [The Idea of the City and Planning Theories]; Technical Transactions, Architecture, 2015; 12-A/2015, 12-A (27), 2015 (112); p. 9-27 [46].
} 
Szersze omawianie typów modeli stosowanych w planowaniu urbanistycznym i gospodarce przestrzennej wykracza poza granice tego artykułu. Tu ograniczono się jedynie do zasygnalizowania podejść, które odpowiadają współczesnym tendencjom w modelowaniu relacji między systemami transportowymi i zagospodarowaniem przestrzennym, a jednocześnie są dorobkiem środowiska planistycznego w Polsce. Wymienić tu należy, przede wszystkim, kierowane przez prof. Tadeusza Zipsera prace nad doskonaleniem autorskiej koncepcji modelu pośrednich możliwości (Zipser T., 1988, 2006, 2010). Znalazły one najbardziej rozwiniętą postać w modelu symulacyjnym pośrednich możliwości ORION ${ }^{5}$ (Zipser, Sławski, 1988, Litwińska, 2010, Mlek, 2010, Ossowicz, 2010)[22 40]. Natomiast w ,szkole krakowskiej” planowania i projektowania systemów transportowych od kilku dekad prowadzone są intensywne prace studialne i koncepcyjne nad rozwojem modeli transportowych typu ,newtonowskiego" (grawitacji i potencjału) oraz próby powiązania tych modeli z planowaniem miast. Omówienie efektów tych prac znajdziemy w publikacjach następujących autorów: Rudnicki, A.(2010), Szarata, A.(2010), Faron A., (2010), [31, 6].

W rozważaniach nad planistycznymi modelami miast przyszłości nie sposób pominąc szerszego tła dyskusji - łącznie z filozoficzną i futurologiczną refleksją nad przyszłością struktur urbanistycznych. Wyróżnić tu można, co najmniej, dwa nurty: idealizujący (dotyczący tzw.: miast idealnych, urbanistycznych utopii i urbanistycznych dystopii) oraz pragmatyczny: odnoszący się do kierunków zmian rzeczywistości miejskiej podbudowanych badaniami tych uwarunkowań rozwoju sytuacji na tym polu, które mają bezpośrednie przełożenie na pragmatykę strategicznego zarządzania rozwojem miejskim. Uwagi na temat nurtu pierwszego wypadałoby rozpocząć komentarzem do współczesnych badań na temat ewolucji doktryn urbanistycznych oraz miasta idealnego, i tu nie sposób pominąć prac takich autorów jak: Gzell (2015), Lorens P., Mironowicz I. (2013), Paszkowski (2011). [8, 19, 23]

Wg. prof. Zbigniewa Paszkowskiego: „Owocem nowych teorii urbanistycznych powinny stać się rozwiąania przestrzenne, $w$ skrócie „,wspótczesne miasta idealne" odpowiadajace potrzebom spotecznym. Powinny być one wynikiem badań naukowych i kreatywnej działalności urbanistów, nie zaś efektem komercyjnej dziatalności deweloperskiej". (Paszkowski, 2011, s.276). Do tego cytatu można byłoby dodać jedno zdanie komentarza: W nurcie idealizującym pogląd ten broni się w zupełności, ale w nurcie pragmatycznym należałoby chyba zmodyfikować ostatnią frazę pisząc: „....nie tylko efektem komercyjnej działalności developerskiej". Oznacza to, że w warunkach demokratycznej i społecznej gospodarki rynkowej realna obrona idei dobra wspólnego i innych wartości wysoko cenionych wymaga partnerskiej współpracy między sektorem prywatnym i publicznym.

\footnotetext{
${ }^{5} \mathrm{~W}$ modelu tym istotną rolę odgrywają: zasada koncentracji, pojęcie selektywności kontaktów oraz takie kwestie jak: symulacje alokacyjne oparte na analizie mechanizmu pośrednich możliwości, symulacyjna ocena potencjału struktur osadniczych i symulacyjna ocena tendencji rozwojowych.
} 
Współpraca ta powinna dotyczyć budowania miejskich systemów przestrzeni publicznych i ochrony dziedzictwa. Oba te zadania muszą znaleźć nowe - bardziej aktualne - rozwiązania w ramach dyskusji nad modelem miasta przyszłości.

Jak podkreślają Danuta i Mieczysław Kochanowscy: „Skuteczna integracja miejskich struktur powinna być jednym z podstawowych celów działań gospodarzy miasta, niezależnie od tego, czy dotyczy powstajacych nowych struktur czy przekształceń i rewitalizacji istniejących. Z natury rzeczy oznacza ona zespót dziatań zmierzajacych do zwiększania sity zwiazków i relacji wewnętrznych budujacych taka spoistość struktur, aby mogły one konkurować z relacjami zewnętrznymi, które zwtaszcza w regionach zurbanizowanych zyskaty niebywale na intensywności dzięki nowym środkom technicznym”. (Kochanowska, D., Kochanowski, M., 2012, s.145). W redefiniowaniu tych relacji istotną rolę odgrywają: współczesna doktryna konserwatorska (Kadłuczka, 2015), kwestie metodologiczne dotyczące interpretowania wartości dziedzictwa kultury (Szmygin, 2015) oraz związki tego pojęcia z nowymi tendencjami w filozofii dziedzictwa (Araoz G. F., 2015; Kadłuczka A., 2014, 2015). Przenosząc te wątki dyskusji na grunt urbanistyki dotykamy pojęcia „,dziedzictwa urbanistycznego”. Przyjęcie takiej perspektywy oznacza konieczność myślenia o dziedzictwie kultury miejskiej (obiektach i urbanistycznych zespołach zabytkowych) w kategoriach systemowych - także w kategoriach tzw.: ,konstrukcji urbanistycznej”. Oznacza to, że aby zbudować model zintegrowanej ochrony dziedzictwa należy rozwiązać „konstrukcyjne" problemy rozwoju miasta, czyli problemy jego integracji przestrzennej, kulturowej, społecznej i instytucjonalnej (Zuziak Z.,2015. s. 20).

W ujęciach pragmatycznych, nowe perspektywy integracji struktur miejskich znajdujemy w koncepcjach miast ekologicznych oraz praktycznych realizacjach idei utożsamianych ze strategiami typu Smart City. Odnosząc się do nich, Prof. Elżbieta Węcławowicz-Bilska wyraźnie rozróżnia trzy typy podejść i odpowiadające im trzy typy miast:

- miasto ekologiczne (Eco City),

- miasto inteligentne (miasto inteligentnych społeczności: z ang.: Intelligent City, Intelligent Community),

- miasto inteligentnych urządzeń (Smart City); (Węcławowicz-Bilska, 2016, s.125).

Interesującym nurtem urbanistyki współczesnej są też analityczne powiązania systematyki miast typu Smart City w ze studiami przypadków i analizami porównawczymi odpowiadającymi tej kategorii miast przyszłości. Literatura tego przedmiotu jest już dość bogata. Tu warto przywołać prace poświęcone strategiom rozwoju Wiednia (Smart City. Framework strategy, 2014; Smart City, 2012) oraz studia porównawcze opracowane w monografii pt.: Stadtmachen. Eu. Urbanity and the Planning Culture in Europe [19]. Wśród rozlicznych źródeł inspiracji, jakimi służyć mogą przykłady dobrej praktyki wskazujące na praktyczne stosowanie modeli planistycznych w urbanistyce, na szczególną uwagę zasługuje przypadek Kopenhagi. Ściślej, należałoby tu mówić o wpływie, jaki na rozwój tego 
miasta miał słynny „Plan Palczasty” i jego ewolucja w okresie 60 lat (1947$2007)^{6}$.

Oczywiście przegląd idei miasta przyszłości - i przykładów ich wdrażania to przedsięwzięcie wykraczające poza ramy tego artykułu. Tu warto jednak zwrócić uwagę na kryteria klasyfikacji podejść do idei miasta przyszłości. W systematyce europejskich modeli PSM stosuje się następujące kryteria:

- uznawane powszechnie wartości (,,ideowe wyznaczniki”);

- kryteria warsztatowe, jak np. technologiczna dojrzałość PSM;

- główne tryby i narzędzia sterowania zmianami strukturalnymi (Zuziak, 2015).

Modele urbanistycznej struktury można również usystematyzować wg idei planistycznych, czyli głównych założeń doktrynalnych przenikających dany system planowania urbanistycznego, bądź też stojących u podstaw (explicite lub implicite) określonych koncepcji planistycznych. W takiej systematyce sprawą kluczową jest stosunek planowania do systemu wartości. I tak, można tu mówić o następujących typach planowania:

- planowanie pragmatyczne, czyli planowanie wykorzystujące w procesie decyzyjnym modele wyjaśniające mechanizmy zmian bez wyraźnego odniesienia do systemu wartości (value free planning);

- planowanie o sporym ładunku motywacji ideologicznej; tu można usytuować zarówno, opozycyjne w stosunku do siebie, planowania: liberalne/neoliberalne i ,socjalizujące”, jak i planowanie wpisujące się w nurt urbanistyki proekologicznej (Zuziak, 2015).

Spośród zbioru atrybutów, jakie urbanistyczne ideologie przypisują miastu przyszłości, najczęściej postulowanymi są trzy następujące kategorie wartości: konkurencyjność, sprawiedliwość społeczna i harmonizowanie rozwoju. Pozostaje jednak kwestią otwartą, w jakiej mierze owe kryteria znajdują realne odzwierciedlenie w praktyce planowania miast i jak przekładają się na planistyczne koncepcje miasta przyszłości. Być może najłatwiej odpowiedzieć na to pytanie odwołując się do planowania urbanistycznego w modelu neoliberalnym. Wymienionym wyżej wartościom wysoko cenionym odpowiadają tu planistyczne procedury negocjacyjne kojarzące trzy kategorie polityk rozwoju: proekologiczną politykę równoważenia rozwoju i struktur przestrzennych, politykę integrowania struktur przestrzennych i społeczno-kulturowych oraz politykę koncentrowania potencjału w miejscach / rejonach węzłowych oraz korytarzach odznaczających się atrakcyjnością pod względem lokalizacji i formy architektoniczno-urbani-

\footnotetext{
${ }^{6}$ Kolejne edycje tego planu, co prawda modyfikowały jego pierwotne założenia, ale utrzymywały zasadniczą ideę. Planowanie Kopenhagi to temat, który wkroczył już do kanonu literatury urbanistycznej (Copenhagen Municipal Plan 1993.,1993 [3] oraz: Jessen i inni, 2008).

7 Mowa tu o wartościach, które doktrynie prawnej uznawana są jako „wartości wysoko cenione”. Por.: Zuziak, 2017.(op. cit).
} 
stycznej. W konsekwencji, charakterystyczną tendencją współczesnego planowania urbanistycznego jest przyjmowanie korporacyjnego modelu planowania miast wyrażające się tzw. planowaniem przez projekty i konfigurowaniem projektów jako strategia harmonizowania zmian w policentrycznej strukturze obszarów metropolitalnych. Pamiętajmy jednak, że niezależnie od ładunku ideologicznego wkomponowanego $\mathrm{w}$ dany system planistyczny jego reguły dotyczą przede wszystkim kwestii proceduralnych, dlatego w przypadku modeli planistycznych symulacje rzeczywistości urbanistycznej nie mogą abstrahować od trybów podejmowania decyzji w ramach określonych reguł prawnych służących racjonalnemu sterowaniu zmianami w zagospodarowaniu przestrzeni. Jest to jedno z założeń, jakie tkwiły u podstaw prezentowanej tu koncepcji planistycznego modelu PSM.

\section{Planistyczny model PSM: koncepcja ,strategicznych wiązań” (strategic connectors)}

Zakładając, że budowa miasta przyszłości wymaga zmian „konstrukcyjnych” o charakterze modelowym, w wypowiedzi tej przedstawia się koncepcję metodologiczną, która pozwala zidentyfikować nowe elementy konstrukcyjne rozwoju struktury urbanistycznej. W tej części publikacji omówione zostaną niektóre planistyczne aspekty studiów i koncepcji nad modelem PSM będących rezultatami projektu badawczego pt.: Model przestrzennej struktury Krakowa. Perspektywa planistyczna, opracowanego, w latach 2016-17, przez zespół architektów, urbanistów i inżynierów transportu z Politechniki Krakowskiej ${ }^{8}$. Projekt ten dotyczył modelowej interpretacji konstrukcyjnych, morfologicznych i funkcjonalnych atrybutów przestrzennej struktury Krakowa. Przedstawiony tu model ma być modelem planistycznym ${ }^{9}$ - planistycznym narzędziem pomocnym $\mathrm{w}$ definiowaniu konstrukcji urbanistycznej miasta $\mathrm{w}$ toku sporządzania planu zagospodarowania przestrzennego. Stąd modelowane elementy przestrzennej struktury, i ich atrybuty, wyraża się językiem planistycznym, tzn. w formie zapisów graficznych i ustaleń tekstowych. Zauważmy jednak, tendencje te nie są w stanie przezwyciężyć widocznego kryzysu planowania, a także kryzysu miasta. Jego oznakami są:

\footnotetext{
${ }^{8}$ Opracowanie wykonano na zlecenie Biura Planowania Przestrzennego Urzędu Miasta Krakowa, przez Zespół w składzie: autorzy: dr hab. inż. arch. Mateusz Gyurkovich (Kierownik Projektu), dr hab. inż. Andrzej Szarata, Prof. PK, prof. dr hab. inż. arch. Zbigniew K. Zuziak; współautorzy: dr inż. Aleksandra Faron, dr inż. arch. Daniel Ogrodnik, dr inż. arch. Anna Ziobro; współpraca: dr inż. arch. Agnieszka Matusik, PhD. Arch. Adolf Sotoca Garcia (Prof. - ETSAV, Barcelona), mgr inż. arch. Szymon Szczepan Baran, mgr inż. arch. Adam Derlatka, mgr inż. arch. Mirosław Maniecki, mgr inż. Justyna Mielczarek, mgr inż. arch. Damian Poklewski-Koziełł, mgr inż. arch. Aneta Sarga, mgr inż. arch. Karolina Studencka, mgr inż. arch. Filip Suchoń, mgr inż. arch. Paulina Tota, inż. Krystian Banet.

${ }^{9}$ Planistycznym modelem przestrzennej struktury miasta nazywa się tutaj procedury badawcze prowadzące do zapisu i interpretacji tych cech przestrzennej struktury miasta, które mają istotne znaczenie dla integrowania przestrzeni miejskiej i równoważenia jej struktury.
} 
polaryzacja, wzrost napięć społecznych (,ku miejskiej rewolucji”) i tendencje odśrodkowe a także wciąż poważne zagrożenia ekologiczne i terrorystyczne ( $\mathrm{Zu}$ ziak, 2015).

Prezentowany tu model jest swego rodzaju kombinacją modelu opisowego, probabilistycznego i normatywnego. Na podstawie przeprowadzonych badań opisuje charakterystyczne cechy przestrzennej struktury miasta a w określonym zakresie - dotyczącym głównie relacji: transport a logika formy urbanistycznej zawiera również interpretacje mechanizmów strukturotwórczych i na tej podstawie wskazuje tez prawdopodobne kierunki rozwoju. W części koncepcyjnej, przez odniesienia do systemu wartości wysoko cenionych, ma również cechy modelu normatywnego.

Główne pojęcia stosowane w modelu to: konstrukcja urbanistyczna, miejskie węzły mobilności, węzły miejskości, korytarze miejskie i strategiczne wiązania.

Konstrukcja urbanistyczna to układ przestrzenny integrujący - pod względem funkcjonalnym i morfologicznym - strukturalne elementy miasta. Dotyczy to zwłaszcza takich elementów jak: korytarze miejskie, miejsca węzłowe (węzły mobilności, węzły miejskości) i obszary strukturalne.

Miejskie węzły mobilności - to miejsca węzłowe sieci transportu zbiorowego, w których koncentrują się funkcje towarzyszące podróży a także innych funkcje centrotwórcze i ruchotwórcze (np.: rejony węzłów przesiadkowych).

Węzły miejskości - to miejsca / skupiska miejsc, które ze względu na dostępność, walory zagospodarowania przestrzennego i inne wartości stanowiące o ich atrakcyjności, mają istotne znaczenie dla współczesnych form życia miejskiego. Istotnym wyznacznikiem węzła miejskości są przestrzenie publiczne - także te o znaczeniu lokalnym - oraz miejsca i obiekty o szczególnych wartościach kulturowych bądź funkcjonalnych (zwłaszcza obiekty publiczne ale także inne obiekty ważne dla życia publicznego). Węzły miejskości są znaczącymi w skali miasta koncentracjami funkcji usytuowanymi przy węzłach mobilności i ,zielonych korytarzy".

Korytarze miejskie to liniowe/pasmowe elementy zagospodarowania przestrzennego usytuowane wzdłuż głównych kierunków komunikacyjnych. Innymi słowy, są to znaczące w skali miasta elementy infrastruktury transportowej wraz $\mathrm{z}$ towarzyszącą im zabudową. Korytarze miejskie odgrywają istotną rolę w integrowaniu struktury przestrzennej miasta.

Strategiczne wiązania (strategic connectors) to miejskie korytarze zabudowy wiążące główne klastry miejsc węzłowych / klastry węzłów miejskości a zarazem kierunki wzdłuż których należałoby skupiać strategiczne projekty miejskie. „Strategiczne wiązania" odgrywają w modelu rolę szczególną, bowiem zakłada się, że taka koncentracja projektów miejskich pozwoli na uzyskanie efektu synergii.

Model PSM pomyślano jako syntezę trzech typów modeli: strukturalnego, morfologicznego i transportowego, ale w tym artykule akcent położono na konstrukcyjne i planistyczne aspekty tego modelu. Kluczowe znaczenie ma tutaj iden- 
tyfikacja konstrukcji urbanistycznej miasta ${ }^{10} \mathrm{i}$ ocena jej potencjału strukturotwórczego. Kluczowym założeniem metodologicznym i koncepcyjnym modelu jest przekonanie, że spośród relacji funkcjonalno-przestrzennych które znacząco wpływają na rozwój miasta, zdefiniowanie relacji między transportem i innymi elementami zagospodarowania przestrzennego należy do podstawowych zadań planowania przestrzennego. Zrozumienie relacji między wzorcami mobilności i systemem transportowym, z jednej strony, a pozostałymi elementami konstrukcji urbanistycznej, z drugiej, zwiększa prawdopodobieństwo planistycznego generowania pozytywnej synergii między projektami urbanistycznymi (Zuziak, 2017).

Opracowany dla Krakowa model charakteryzuje strukturę przestrzeni urbanistycznej na podstawie analizy logicznych związków zachodzących między głównymi elementami struktury przestrzennej miasta oraz czynnikami wpływającymi na te relacje. Mowa tu o tak podstawowych czynnikach zmian strukturalnych jak a) polityki sektora publicznego, b) wzorce zachowań indywidualnych podmiotów „gry o przestrzeń” i c) wartości jakimi w tej grze kierują się zarówno podmioty publiczne jak i indywidualne. Innymi słowy, model składa się z pięciu warstw tematycznych. Pierwszą tworzy materia urbanistyczna, czyli: elementy struktury przestrzennej, siatki urbanistyczne i tkanki urbanistyczne. Warstwa druga to relacje miedzy elementami, siatkami i tkankami, a trzy następne warstwy to: polityki, wzorce i wartości, a więc zbiory czynników strukturotwórczych - czy jak kto woli - trzy kategorie potencjalnych - a zarazem najważniejszych - oddziaływań na relacje między elementami struktury przestrzennej.

\section{Modelowanie konstrukcji urbanistycznej Krakowa}

Poprzedniki ideowe - Prezentując koncepcję modelu PSM Krakowa warto zwrócić uwagę na jej ,ideowe poprzedniki”. Począwszy od lat 70. można tu wymienić sześć następujących modeli:

- Model Seiberta ${ }^{11}$ - (1977) metropolitalny układ pasmowo-węzłowy, rusztowy. Ta interpretacja modelowa wiąże się z pracami studialnymi i koncepcyjnymi wykonanymi w ramach Planu Krakowskiego Obszaru Miejskiego (KZM) ${ }^{12}$.

- Model OSA ${ }^{13}$ - wykonany przez zespół pod kierunkiem prof. Stanisława Juchnowicza. Podstawą modelu były badania nad zachowaniami lokalizacyjnymi na początku lat 80-tych.

\footnotetext{
${ }^{10}$ Konstrukcja urbanistyczna miasta to układ przestrzenny integrujący - pod względem funkcjonalnym i morfologicznym - jego elementy strukturalne. Dotyczy to zwłaszcza takich elementów jak: korytarze miejskie, miejsca węzłowe (węzły mobilności, węzły miejskości) i obszary strukturalne.

${ }^{11}$ Dr inż. arch. Krystian Seibert był generalnym projektantem tego planu.

${ }^{12}$ Model ten podbudowano regionalnym modelem ORION prof. Tadeusza Zipsera. Wykazywał też związki z modelem ,optymalizacji warszawskiej”. Podkreślenie wpływu lokalizacji kombinatu HIL na układ KZM.

${ }^{13}$ OSA to akronim od: Ogniska Społecznych Aktywności.
} 
- Modele Ziobrowskiego ${ }^{14}$ (II-ga poł. 80 i lata 90.) - model układu promienisto-obwodnicowego odpowiadający idei „Miasto zwartego" i akcentujący wpływ projektów strategicznych na rozwój miasta (także: kampusów uniwersyteckich).

- Model w Studium 2004 - wykazywał znaczny wpływ modelu Ziobrowskiego. Podkreślał rolę głównych ulic miejskich i rolę miejskich centrów wielofunkcyjnych a także strategicznych projektów rewitalizacji terenów poprzemysłowych.

- Model J.M. Chmielewskiego ${ }^{15}$ - opracowany w okresie 2009-2012 w ramach prac nad studium uwarunkowań rozwoju Krakowa - wprowadza nowa koncepcję obwodnicy śródmieścia. akcentuje też rolę wielkopowierzchniowych obiektów handlowych traktowanych jako potencjalnych zalążków przyszłej struktury policentrycznej.

- Model w Studium 2014 ${ }^{\mathbf{1 6}}$ - definiuje układ przestrzenny miasta jako „mieszany” jednak z dominacją układu promienisto-obwodnicowego. Model deklaruje związek z ideą "miasta zwartego" i definiuje PSM jako metropolitalną strukturę policentryczną. W modelu tym istotną rolę odgrywają: reinterpretacja systemu zieleni, strukturalne jednostki urbanistyczne oraz nowy zestaw strategicznych projektów miejskich ${ }^{17}$.

Model Kr2016 - Pod względem geometrii układu przestrzennego, proponowaną tutaj interpretację PSM określić można jako układ mieszany ${ }^{18} \mathrm{z}$ wyraźną przewagą układu promienisto-obwodnicowego układu zabudowy śródmieścia. Pod względem kompozycyjnym i funkcjonalnym układ ten jest nadal słabo powiązany z czytelnym układem urbanistycznym zabytkowej części Nowej Huty oraz naturalnie i kulturowo uformowaną siecią przyrodniczych i kulturowych elementów wyznaczających tożsamość urbanistycznego dziedzictwa Krakowa (ryc. 1). W aktualnej strukturze funkcjonalnej i przestrzennej Krakowa nakładają się parami następujące typy: a) promienisto-obwodnicowy i pasmowy oraz b) monocentryczny i policentryczny. $Z$ jednej strony wyraźna jest dominacja historycznego centrum i śródmieścia oraz „obumieranie” historycznego miasta Nowa Huta, ale z drugiej,

${ }^{14}$ Prof. dr hab. inż. arch. Zygmunt Ziobrowski był generalnym projektantem Planu Ogólnego Zagospodarowania Przestrzennego Krakowa uchwalonego a 1988r

${ }^{15}$ Prof. dr hab. inż. arch. Jan Maciej Chmielewski był generalnym projektantem I Części Studium Uwarunkowań i Kierunków Zagospodarowania Przestrzennego Krakowa (Cz. pt.: Uwarunkowania).

${ }^{16}$ Studium Uwarunkowań i Kierunków Zagospodarowania Przestrzennego Krakowa (uchwalone w 2014r.) opracował zespół pod kierunkiem mgr inż. arch. Elżbiety Koterby - Z-cy Prezydenta Miasta Krakowa.

${ }^{17}$ W znacznej mierze w modelu przyjętym w Studium 2014 wykorzystano założenia modelowe koncepcji opracowanych $w$ ramach seminarium konkursowego zorganizowanego przez UMK w 2012r.

${ }^{18}$ Istnieją również powody uzasadniające aby taki układ traktować jako hybrydowy (Gyurkovich M., 2013, 2016).[9] 
dostrzegalne są oznaki krystalizowania się obszarów skupiających kilka miejsc węzłowych (klastry węzłów miejskości). Wskazuje to, że - zgodnie z założeniami przyjętymi w Studium 2014 - Kraków wchodzi w fazę formowania się układu metropolitalnego.

$\mathrm{W}$ świetle badań i analiz przeprowadzonych $\mathrm{w}$ ramach projektu badawczego większość ustaleń Studium z 2014 r. pozostaje w mocy. Istnieją jednak obszary tematyczne, które wskazują na celowość - a właściwie nawet na pilną konieczność - przystąpienia do jego aktualizacji. Zmiany te powinny polegać przede wszystkim na wprowadzeniu procedur umożliwiających:

- lepsze wykorzystanie rozwojowych / strukturotwórczych potencjałów konstrukcji urbanistycznej wyznaczonych zarówno w Modelu Kr2016 jak i tych proponowanych w koncepcji modelowej Kr2013/50;

- skuteczniejszą / pełniejszą ochronę wartości przyrodniczego i kulturowego dziedzictwa;

- konkretyzację ustaleń planistycznych dotyczących Parku Rzeki Wisły głównego korytarza zielonego z poprzecznymi powiązaniami w postaci ciągów pieszych i rowerowych, integrujących rzekę z ogniskami aktywności położonymi w bezpośrednim otoczeniu.

- mocniejsze wyartykułowanie ustaleń planistycznych pozwalającym bardziej skutecznie przeciwdziałać chaotycznemu dogęszczaniu zabudowy osiedli mieszkaniowych;

- sformułowanie ustaleń planistycznych pobudzających działanie mechanizmów intensyfikacji zabudowy; dotyczy to przede wszystkim bardziej racjonalnego wykorzystania terenu w korytarzach zabudowy odznaczających się dobrą dostępnością do przystanków transportu zbiorowego (szynowego);

Model Kr-2030/50 - W wizji Kr2030/50 akcentuje się strukturotwórczą rolę głównych korytarzy transportu zbiorowego oraz systemu zieleni. Oznacza to, że w warunkach polityki zrównoważonej mobilności głównym szkieletem urbanistycznym miasta jest układ spinający Zachodni Klin Zielony Krakowa, Korytarz rz. Wisły i inne strukturalne korytarze zieleni miasta. Jednocześnie wskazuje się następujące - pożądane i prawdopodobne - zasady i kierunki zmian w strefach /,klinach” i korytarzach zabudowy i zieleni. Pod względem geometrii układu przestrzennego, rekomendowany Model Kr2030/50 można nazwać układem hybrydowym. Oznacza to, że mamy tu do czynienia z dwoma typami siatek, które wyznaczają dwa układy odniesienia dla powiązań pomiędzy SJU (strukturalnymi jednostkami urbanistycznymi) i klastrami węzłów miejskości. Powiązania te rozważań należy uwzględniając przyrodnicze, funkcjonalne, technologiczne, społeczno-ekonomiczne i kompozycyjne aspekty życia miejskiego, a zarazem kryteria oceny poziomu ładu przestrzennego - czy też zrównoważenia / zharmonizowania struktury miejskiej. Mówiąc o dwóch typach siatek mamy tu na myśli: 
a),siatkę przyrodniczą", którą wyznaczają rzeki, korytarze oraz kliny i inne obszary zieleni oraz b) siatkę kontaktów i powiazań transportowych między klastrami węzłów miejskości. W sensie konstrukcyjnym, najważniejszą częścią modelu $\mathrm{Kr}-20 / 50$ jest koncepcja nowych ,wiązań strategicznych

\section{Konstrukcja urbanistyczna Rzeszowa: kwestie modelowania i nowej wizji}

Badania nad rozwojem potencjałów strukturotwórczych Rzeszowa i jego obszaru funkcjonalnego (Kotarski, Malicki, 2013; Morawski, 2014; Rykiel, Kinal, 2015) wskazują, że pod wieloma względami hasło: ,miasto przyszłości” jest w tym przypadku uzasadnione. Dotyczy to zarówno charakterystyki struktury funkcjonalnoprzestrzennej miasta i wartości jego dziedzictwa kultury jak również oceny jego perspektyw gospodarczych i kapitału społecznego.[18]

W XX wieku imponujący awans miasta rozpoczął się już w późniejszym okresie PRL-u, zwłaszcza od lat sześćdziesiątych (Kotarski, Malicki, 2013, s.19). Po trudnych dla gospodarki miasta latach dziewięćdziesiątych, w pierwszej dekadzie XXI w. pojawiły się znaczące impulsy rozwojowe ${ }^{19}$. Sprawiły one, że wśród miast polskich, Rzeszów jest jednym z najbardziej dynamicznie rozwijających się ośrodków (Kotarski, Malicki, 2013); centrum regionalnym które konsekwentnie wzmacnia swoje potencjały konkurencyjne w innowacyjnych sektorach gospodarki.

Rzeszów jest miastem, którego obszar funkcjonalny zalicza się do potencjalnych obszarów metropolitalnych. Omawiając społeczne i ekonomiczne aspekty procesów urbanizacji i metropolizacji w regionalnych metropoliach Polski Wschodniej, prof. Zbigniew Rykiel i dr Jarosław Kinal bronią hipotezy, że: „Rzeszów ma nie mniejsze szanse rozwoju funkcji metropolitalnych niż Bydgoszcz $i$ Lublin". Analizując wskaźniki metropolitalności Rzeszowa wymienieni autorzy wskazują - między innymi - że miasto to zajmuje ,korzystna pozycję $w$ stosunku do liczby swych mieszkańców oraz na tle Polski Wschodniej, gdzie bezwzględna ranga metropolitalna Rzeszowa jest wyższa niż Biategostoku, ale już nie Lublina". (Rykiel, Kinal, 2014, s.72).[27]

Podkreślić też należy strukturotwórczą rolę potencjałów urbanistycznego dziedzictwa kultury - i to nie tylko w zabytkowych rejonach śródmieścia Rzeszowa. Aktualnie prowadzone badania wskazują również na wartości kulturowego dziedzictwa modernistycznych osiedli mieszkaniowych (Gosztyła, Mazur, 2016), a prace nad programem rewitalizacji (Noworól, z Zespołem, 2010) dowodzą, że wartości te mogą odegrać istotną rolę w budowaniu nowej konstrukcji urbanistycznej Rzeszowa.[7]

19 Tymi impulsami były: rozwój przemysłów: lotniczego, informatycznego, farmaceutycznego, branż sprzętu gospodarstwa domowego i spożywczego a także funkcji nauki i szkolnictwa wyższego. 
W tym miejscu zauważmy, że trafność wniosków, jakie wynikają z owych badań, a także odpowiadających im spekulacji, założeń i rozwiązań koncepcyjnych co do kierunków zmian dotyczących struktury funkcjonalno-przestrzennej miasta, zależeć będzie - w znacznej mierze - od konsekwencji, z jaką samorząd lokalny będzie wdrażał (przy wsparciu samorządu regionalnego i władz rządowych) zasady polityki przestrzennej zapisane w aktualnym (2000 / 2009 r.) Studium Uwarunkowań i Kierunków Zagospodarowania Przestrzennego Miasta Rzeszowa.

W dyskusji nad interpretacją dotychczasowych zmian w konstrukcji urbanistycznej Rzeszowa - i koncepcją jej rozwoju - punktem wyjścia jest oczywiście diagnoza sytuacji urbanistycznej: identyfikacja elementów strukturalnych, powiazań między nimi oraz uwarunkowań ich rozwoju - określanych także w kontekście regionalnym. W przypadku badań nad modelem PSM - Rzeszów 2017, podobnie jak w przypadku omawianych tu badań i rozwiązań modelowych dotyczących PSM Krakowa, oznaczałoby to konieczność identyfikacji takich elementów konstrukcyjnych jak: korytarze i węzły miejskości, klastry węzłów miejskości oraz ustalenie geometrii ,strategicznych wiązań” w nawiązaniu do aktualnie wyznaczonych w Studium i w Strategii Rozwoju Miasta obszarów i projektów strategicznych (Raińczuk, $2000 / 2014)^{20}$.

Równie ważnymi blokami tematycznymi koncepcji metodologicznej modelu PSM są: model transportu publicznego i model przestrzennej struktury Śódmieścia Akcentując relacje strukturalne między zmianami w użytkowaniu terenu i rozwojem systemu transportu - a także kontekst regionalny uwarunkowań rozwoju elementów PSM, które w horyzontach czasowych przyjmowanych w planowaaniu przestrzennym tworzyć będą konstrukcję urbanistyczną Rzeszowa - należy zwrócić uwagę na wyniki badań przeprowadzonych w ramach wspólnego projektu zespołów badawczych z Politechniki Warszawskiej i Politechniki Krakowskiej pt.: Uwarunkowania i Kierunki Związane z Systemem Transportowym $^{21}$. Autorzy tego projektu zwracają uwagę, że: „Wszystkie cele rozwoju systemu transportowego w kraju moga zostać odniesione także do Rzeszowa". $\mathrm{W}$ opracowaniu przedstawiono wariantowe propozycje rozwoju transportu publicznego z uwzględnieniem takich środków jak: kolej jednoszynowa (Monorail), BRT (Bus Rapid Trasnsit) i tradycyjny tramwaj.

$\mathrm{Wg}$. proponowanej tu metody, kolejnym krokiem procedur modelowania byłaby analiza porównawcza modelu R2017 z ustaleniami aktualnie obowiązującego Studium oraz bardziej szczegółowe analizy przeprowadzone dla śródmieścia

${ }^{20}$ W Załącznikach do Studium (Rainczuk, 2014) czytamy: „Określono 14 obszarów strategicznych o łącznej powierzchni 1506,9ha, co stanowi około 12,9\% powierzchni miasta, liczącej 11.629 ha. Strategicznych tzn. takich, w których podejmowane działania polegające na przekształceniach istniejącej substancji lub rozwoju, mają znaczenie strategiczne. Służą realizacji przyjętych głównych celów rozwoju miasta, a nawet warunkują ich realizację".

${ }^{21}$ Opracowanie to wykonano na zlecenie Urzędu Miasta Rzeszowa w ramach prac nad Strategią Rozwoju Rzeszowa na lata 2015-2020; [34]. 
i jego „kołnierza urbanistycznego” (miedzy innymi: analizy możliwości i kierunków przekształcenia struktury przestrzennej śródmieścia: analizy konstrukcyjne, morfologiczne i funkcjonalne). W modelu przestrzennej struktury śródmieścia kluczowe zagadnienia to: struktura przestrzenna dziedzictwa urbanistycznego (obszary, węzły i korytarze dziedzictwa; zagadnienia wartościowania i integracji, oraz problemy powiązania centrum z głównym „korytarzem zielonym” miasta, czyli Parkiem rz. Wisłok (,riverfront”) i problemy jego integracji z wyznaczonymi w ramach Studium obszarami strategicznymi (Raińczuk, 2014) a także z innymi, kluczowymi elementami PSM określonymi w skali metropolitalnej. [25]

Kolejny krok to budowanie wizji rozwoju PSM Rzeszowa, czyli modelowa interpretacja głównych elementów konstrukcji urbanistycznej R2030/50 takich jak: węzły i korytarze miejskości o znaczeniu metropolitalnym oraz klastry tych miejsc węzłowych i wariantowe ideogramy powiązań między tymi elementami.

W proponowanej tu metodzie kreowania wizji konstrukcji urbanistycznej miasta artykułuje się rolę integracji struktury śródmiejskiej w skali metropolitalnej. Przy okazji, zwraca się uwagę na takie zagadnienia warsztatowe jak: problem delimitacji śródmieścia i techniki zapisu planistycznego modelowej interpretacja jego śródmiejskiej struktury przestrzennej. Tu wypada przypomnieć badania prof. Stanisława Juchnowicza nad śródmieściami miast polskich prowadzone na przełomie lat 60. i 70. ubiegłego stulecia oraz jego koncepcje architektoniczno-urbanistyczne opracowane w ramach konkursów urbanistycznych poświęconych wizji zagospodarowania przestrzennego badanych śródmieść (Juchnowicz, 1971). W zbiorze tych analiz i projektów koncepcyjnych znalazło się śródmieście Rzeszowa W koncepcji Juchnowicza nt. centrum Rzeszowa główną rolę odgrywała idea kompozycyjna polegająca na wytworzeniu czytelnych i atrakcyjnych pod względem architektoniczno-urbanistycznym powiązań między historycznym centrum a głównym dworcem kolejowym. Nawiązując to terminologii prezentowanego tu modelu, projektowany przez prof. Juchnowicza „kręgosłup kompozycyjny" nowego centrum Rzeszowa powinien być traktowany jako przykład ,strategicznego wiązania", które mogłoby stać się źródłem inspiracji dla nowych prac nad koncepcją śródmiejskiej - a zarazem metropolitalnej - konstrukcji urbanistycznej.

\section{Synteza, podsumowanie}

W prezentowanej koncepcji metodologicznej model PSM rozumiany jest jako idea planistyczna wyrażona $\mathrm{w}$ formie ideogramu struktury przestrzennej oraz odpowiadające temu schematowi tendencji rozwoju i zasad polityki przestrzennej które przez wiele dekad mogłyby być konsekwentnie wdrażane przez samorząd lokalny, natomiast do „miast przyszłości” zaliczono tu miasta, które dzięki swym atrybutom struktury przestrzennej wyznaczają nowe kierunki rozwoju urbanistyki. W tym przypadku nie interesowały nas problemy urbanistyczne, którym poświęcone są wizje „miast idealnych”, czy miast utopii, lecz metodologiczne 
problemy wyprowadzone z pytania: jak skonstruować planistyczny model struktury urbanistycznej pozwalający przełamać trudności związane z tworzeniem rozbudowanych baz danych i prowadzeniem dyskusji publicznej w części, w której wyjaśnianie modelu wymaga odwoływania się do skomplikowanych nieraz algorytmów?

Uwagę skupiono na konstrukcyjnych aspektach modelowania PSM o znaczeniu metropolitalnym oraz roli, jaką w tym modelu odgrywają elementy systemu transportowego traktowane jako osie i punkty centralne korytarzy i węzłów miejskości. Mowa tu zwłaszcza o tych elementach strukturalnych, które nazwano tu ,strategicznymi wiązaniami”. Strategiczne wiązania, to idea, która kojarzy konstrukcyjne, morfologiczne i funkcjonalne aspekty struktury urbanistycznej z kierunkami długofalowej polityki miasta, bowiem wiązania te traktuje się jako osie konfigurowania strategicznych projektów miejskich.

Koncepcja modelowania ma odzwierciedlać dynamikę procesów strukturotwórczych. Oznacza to, między innymi, że formowaniu się struktur metropolitalnych nowej generacji towarzyszy krystalizacja nowych układów policentrycznych oraz znacząca transformacja układów przestrzennych związanych z nauką, szkolnictwem wyższym i przemysłem wysokich technologii a także rozwój innych form zagospodarowania przestrzennego odpowiadających dyfuzji innowacji w gospodarce. Towarzyszą temu również zmiany odpowiadające wdrażaniu strategii rewitalizacji obszarów kryzysowych. Wszystkie te zagadnienia powinny znaleźć swe odzwierciedlenie w modelowej koncepcji konstrukcji urbanistycznej Rzeszowa i zasadach jego długofalowej polityki rozwoju. W wizji tej podkreśla się znaczenie obszarów, miejsc węzłowych i korytarzy o różnych cechach morfologicznych i funkcjonalnych. Mowa tu o historycznym centrum, rejonie głównego dworca kolejowego, a także o potencjalnych obszarach rewitalizacji. W tym sensie kreowanie wizji Rzeszowa jako miasta przyszłości wiąże się z tworzeniem synergicznych relacji między konstrukcyjnymi, funkcjonalnymi i morfologicznymi warstwami modelu planistycznego.

Proponuje się też, aby koncepcja prezentowanego modelu stała się podstawą studiów i badań porównawczych nad zmianami w modelu struktury przestrzennej innych miast polskich podlegających procesom metropolizacji. Konkretyzując założenia metodologiczne modelu posłużono się głównie przykładem Krakowa ale należałoby sprawdzić możliwości aplikacyjne tego rodzaju modelowania PSM w odniesieniu do Lublina i Rzeszowa. W przypadku Rzeszowa zwrócono uwagę na konieczność mocniejszego wyartykułowania elementów konstrukcji urbanistycznej integrującej śródmieście z kluczowymi elementami PSM w skali metropolitalnej. Podkreśla się też znaczenie obszarów, miejsc węzłowych i korytarzy o różnych cechach morfologicznych i funkcjonalnych. Mowa tu o historycznym centrum, rejonie głównego dworca kolejowego, a także o potencjalnych obszarach rewitalizacji. W tym sensie kreowanie nowej wizji rozwoju Rzeszowa jako miasta 
przyszłości wiąże się z tworzeniem synergicznych relacji między konstrukcyjnymi, funkcjonalnymi i morfologicznymi warstwami modelu planistycznego. Zakłada się, że koncepcja metodologiczna prezentowanego modelu może być punktem wyjścia dla studiów i badań porównawczych nad zmianami w modelu struktury przestrzennej innych polskich metropolii.

\section{Literatura}

[1] Alexander, C. (i inni): Generative Codes. The Path to Building Welcoming, Beautiful, Sustainable Neighborhoods, [in:] New Urbanism and Beyond. Designing Cities for the Future, Haas Tigran, (ed.), Rizzoli, New York, 2008.

[2] Araoz G. F.: Tendencje dziedzictwa dziś i jutro - z perspektywy ewolucji filozofii i teorii konserwacji, Wiadomości konserwatorskie 44/2015, s. 9-18.

[3] Boelens, L.: The Urban Connection. An actor - relational approach to urban planning, 010 Publishers, Rotterdam, 2009.

[4] Copenhagen Municipal Plan 1993, The Municipal Corporation of Copenhagen, The Lord Mayor's Department, Copenhagen, 1993.

[5] Domański R.: Gospodarka przestrzenna, Wyd. Naukowe PWN, Warszawa, 2002.

[6] Faron, A.: Integracja planowania przestrzennego i zrównoważonego transportu w procesie decyzyjnym, Czasopismo Techniczne 1-A / 2010 Zeszyt 3 Rok 107 57-74

[7] Gosztyła M., Mazur A.: Architektura mieszkaniowa lat siedemdziesiątych w Rzeszowie, Na przykładzie wybranych osiedli, Oficyna Wydawnicza Politechniki Rzeszowskiej, Rzeszów, 2016.

[8] Gzell S.: Wykłady o współczesnej urbanistyce. With English Supplement on Contemporary Town Planning, Oficyna Wydawnicza Politechniki Warszawskiej, 2015.

[9] Gyurkovich, M.: Hybrid Urban Structures / Hybrydowe Struktury Urbanistyczne, Wyd, PK, Kraków 2016.

[10] Gyurkovich, M.: Hybrydowe przestrzeni kultury we współczesnym mieście europejskim, Monografia 438Wyd, PK, Kraków 2013.

[11] Haas T. (ed):New Urbanism and Beyond. Designing Cities for the Future, Rizzoli, New York, 2008.

[12]Hillier, B.: The New Science of Space and the Art of Place. Towards a Space-led Paradigm for Researching and Designing the City, [in:] New Urbanism and Beyond. Designing Cities for the Future, Haas Tigran, (ed.), Rizzoli, New York, 2008.

[13] Jessen J, Meyer U. M., Schneider J. (ed.): Stadtmachen. Eu. Urbanity and the Planning Culture in Europe (ed. Jessen J, Meyer U. M., Schneider J.), Karl Krämer Verlag, Stuttgart, 2008.

[14] Juchnowicz S.: Śródmieścia miast polskich. Studia nad ukształtowaniem i rozwojem centrów, Zakład Narodowy Imienia Ossolińskich Wydawnictwo Polskiej Akademii Nauk, Wrocław, Warszawa, Kraków, Gdańsk, 1971. 
[15] Kadłuczka, A.: Conservatio est continua creatio - czyli doktryna ochrony dziedzictwa jako komponentu przestrzeni egzystencjonalnej, Wiadomości konserwatorskie 44/2015, s.68-77.

[16] Kadłuczka, A., Idea zrównoważonego rozwoju, a problemy ochrony dziedzictwa kulturowego. Na przykładzie florencki i Krakow, Wiadomości Konserwatorskie Nr 23/2008.

[17] Kochanowska, D., Kochanowski M.: W stronę miasta, Wyższa Szkoła Ekologii i Zarządzania, Warszawa, 2012.

[18] Kotarski, H., Malicki, K.: Stolica Podkarpacia wczoraj i dziś. Studium socjologiczne społecznych aspektów przemian w Rzeszowie w latach 1989-2009, Wydawnictwo Uniwersytetu Rzeszowskiego, Rzeszów, 2013.

[19]Lorens P., Mironowicz I. (pod redakcją): Wybrane teorie współczesnej urbanistyki, Akapit-DTP, Gdańsk, 2013.

[20] Morawski, J. (z Zespołem): Studium programowo-przestrzenne szlaku kulturowego Centralnego Okręgu Przemysłowego na terenie Województwa Podkarpackiego, Marszałek Województwa Podkarpackiego i Biuro Planowania Przestrzennego w Rzeszowie, Rzeszów, 2014. http://www.pbpp.pl (dostęp: 29. 07. 2017).

[21] Noworól, A. (z Zespołem): Program Rewitalizacji Obszarów Miejskich w Rzeszowie na lata 2007 - 2015, Kraków, czerwiec 2010.

[22] Ossowicz T.: Forma urbanistyczna, a system transportowy we Wrocławiu i we Wrocławskim Obszarze Metropolitalnym, Czasopismo Techniczne 1-A / 2010 Zeszyt 3 Rok 107

[23] Paszkowski Z.: Miasto idealne w perspektywie europejskiej i jego związki z urbanistyką współczesną, Universitas, Kraków, 2011.

[24]Putman, S.H.: Integrated Urban Models: Policy Analysis of Transportation and Land Use. (1983 \& 2007): Routledge, Oxford, UK. 2007.

[25] Raińczuk A.: Obszary strategiczne dla realizacji głównych celów polityki społecznogospodarczej i przestrzennej miasta, Załącznik nr 94 do uchwały Nr XXVII/1 13/2000 Rady Miasta Rzeszowa z dnia 4 lipca 2000 r., Rzeszów, 2014.

[26] Rudnicki, A., Zrównoważona mobilność a rozwój przestrzenny miasta. Czasopismo Techniczne 1-A / 2010 Zeszyt 3 Rok 107, s. 57-74

[27] Rykiel, Z., Kinal J.: Metropolie regionalne Polski Wschodniej, [w:] Malikowski M., Palak, J., Halik, M., (pod redakcją): Społeczne i ekonomiczne aspekty urbanizacji i metropolizacji, Wydawnictwo Uniwersytet Rzeszowski, Rzeszów, 2015. s. 65-80.

[28] Smart City Wien. Framework Strategy, Vienna City Administration, Vienna, 2014.

[29] Smart City. Viennese Expertise based on Science and Research, Schmid Verlag, Vienna, 2012.

[30] Sławski J.: Znaczenie systemu transportowego jako czynnika strukturotwórczego analizy symulacyjne z zastosowaniem sieci regularnych, Czasopismo Techniczne 1-A / 2010 Zeszyt 3 Rok 107 
[31] Szarata, A.: Wpływ zmian w strukturze przestrzennej na parametry 4-stadiowego modelu transportowego miasta, Czasopismo Techniczne 1-A / 2010 Zeszyt 3 Rok 107 249-261.

[32] Szmygin B.: Teoria i kryteria wartościowania dziedzictwa jako podstawa jego ochrony, Wiadomości konserwatorskie 44/2015, s.44-52.

[33] Thierstein A., Förster, A., (editors) The Image and the Region-Making - Making Mega-City Regions Visible!, Lars Müller Publishers, München, 2008.

[34] Uwarunkowania i Kierunki Związane z Systemem Transportowym, Raport z realizacji umowy: ZTM/233.55.58/2015, Choromański W; (Kierownik pracy), Szarata, A., (Główny wykonawca), i inni: Strategia Rozwoju Rzeszowa na lata 2015-2020; Politechnika Warszawska i Politechnika Krakowska, Warszawa, 2015.

[35] Węcławowicz-Bilska E.: Miasta i zurbanizowane struktury przestrzenne przyszłości, [w:] Złowodzki M., i inni (pod redakcją) : Ergonomia wobec wyzwań nowych technik i technologii, Politechnika Krakowska, Kraków 2016,s.123-138.

[36] Widmann H., (ed.) Smart City. Viennese Expertise Based on Science and Research, Schmid Verlag, Vienna, 2012

[37] Wrana, J.: Rola i znaczenie architektury w procesie scalania struktury przestrzennej miasta na przykładzie Lublina, Monografia, Politechnika Lubelska, Lublin, 2014.

[38]Zipser T.: Powiązania transportowe jako generatory struktury przestrzennej systemu osadniczego. Czasopismo Techniczne, Zeszyt 3, 2010; 21-30.

[39]Zipser T.: Aktualna doktryna urbanistyczna wśród ślepych uliczek, [w:] Urbanistyka w działaniu. Teoria i praktyka, red.: Ossowicz T., Zipser T., Urbanista, Warszawa, 2006, s. 114-121.

[40]Zipser T., Sławski J.: Modele procesów urbanizacji. Teoria i jej wykorzystanie w praktyce, PWE, Warszawa 1988

[41]Zhong Chen: Urban Transformation Towards Polycentricity. Detecting Functional Urban Changes in Singapore from Transportation Data, A thesis submitted to attain the degree of Doctor of Sciences of ETH Zurich, 2014

[42]Zuziak Z. K.: O synergii planu w urbanistyce, Budownictwo i Architektura 16(1), 2017. S. 183-198.

[43]Zuziak Z. K.: Konstrukcje urbanistyczne a planowanie metropolitalne, [w:] Węcławowicz-Bilska E. (pod redakcją): Nowe idee w planowaniu rozwoju terytorialnego. Problemy obszarów metropolitalnych i wielkich miast, Politechnika Krakowska im. Tadeusza Kościuszki, seria: Monografie: monografia 546, Kraków, 2017, s.17-44.

[44]Zuziak Z. K.: The Notion of Order and the Spatial Logic of a New Polis: Three Approaches to the Problem of Rationality in the Contemporary Philosophy of Urbanism, 11 CTV, Back to the sense of the City, Barcelona, Kraków, 2016.

[45]Zuziak, Z. K.: Urbanism and Cultural Heritage Strategies. Actors and Structures in the Labyrinth of Urbanity, Journal of Heritage Conservation, 43 / 2015, p. 19-32. [Urbanistyka i dziedzictwo kultury. Strategie, aktorzy i struktury w labiryntach miejskości, Wiadomości konserwatorskie 44/2015, s.19-32].

[46]Zuziak, Z. K.: Idea miasta i teorie planowania, [The Idea of the City and Planning Theories]; Technical Transactions, Architecture, 2015; 12-A/2015, 12-A (27), 2015 (112); p. 9-27. 
[47]Zuziak Z. K.: Zmiany strukturalne w miastach polskich na początku XXI . Między sztuką budowania miast a polityką przestrzenną. [w:] Halicka A. (red), Budownictwo na obszarach zurbanizowanych. Nauka, praktyka, perspektywy, Lublin. Politechnika Lubelska; s.165-176, 2014.

[48]Zuziak Z. K.: Strategiczne węzły w przestrzeni przepływów. Czasopismo Techniczne Zeszyt 10, 2011, 41-47.

[49]Zuziak Z. K.: Forma metropolitalna a zrównoważona mobilność. Czasopismo Techniczne Zeszyt 3, 2010, 75-94.

[50]Zuziak Z. K.: O tożsamości urbanistyki. Politechnika Krakowska im. Tadeusza Kościuszki, 2008.

\section{URBAN CONSTRUCTIONS AND THE CITIES OF THE FUTURE. REMARKS ON THE DEVELOPMENT VISION FOR THE CITY OF RZESZOW}

\section{S u m m a r y}

In the paper, the role of modeling urban spatial structure is discussed in the context of spatial planning process for the cities which are having potentials for the development of metropolitan functions and are revealing aspirations to be recognized as "the city of the future". The main focus is put on structural aspect of modeling metropolitan space. Assuming that building the city of the future implies the change of the model - particularly in relations between transport systems and land use, the author outlines a new proposal for modelling metropolitan spatial structure based on the research project carried out for the city of Kracow by the team of architects, urbanists and civil engineers from the Cracow University of Technology. The key phrases of this model are: connectivity, urban construction and strategic connectors. This applies to such major components of spatial structure of the city as: the nodes and the corridors of urbanity and the network of public spaces. The model allows for the identification of new structural elements of urbanistic space as well as potential synergic relations between them. In the interpretation of urban connectivity significant role is played by strategic connectors - urban corridors linking major clusters of the nodal places and thus having potentials for concentrating strategic urban projects. It is assumed that this type of concentration helps to achieve the effect of urban synergy. Although the model was developed for the city of Krakow, references to the city Rzeszow are also made. In this case attention was drawn to potential strategic connectors linking the historic center - and other main nodes of urbanity within the inner city - with new potential metropolitan clusters of urban nodes such as close-to-station areas as well as potential areas of urban revitalization. It is emphasized that nodal places, corridors of urbanity, and strategic areas should be diversified in terms of morphological and functional attributes. It is assumed that the model presented in this paper could be used as a starting point for further comparative analyses within the framework of a collaborative project carried out by the joined university research team from the cities of Krakow, Lublin and Rzeszow.

Keywords: urbanism, spatial planning, urban construction, model of spatial urban structure, connectivity, strategic connectors, urban synergy.

Przestano do redakcji: 09.06.2017 $r$.

Przyjęto do druku: 01.09.2017 r. 
